How to cite this article:

Al Qurtuby, S. (2020). The rise of Islamism and the future of Indonesian Islam. Journal of International Studies, 16, 105-128. https://doi.org/10.32890/jis2020.16.7

\title{
The Rise of Islamism and the Future of Indonesian Islam
}

\author{
Sumanto Al Qurtuby \\ Department of Global \& Social Studies \\ College of General Studies \\ King Fahd University of Petroleum \& Minerals \\ alqurtuby@kfupm.edu.sa
}

Received: 6/4/2020

Revised: $28 / 6 / 2020$

Accepted: 12/7/2020

Published: $30 / 12 / 2020$

\begin{abstract}
Since the downfall of Suharto's dictatorial regime in 1998, Indonesia has witnessed a surge of various Islamist groups that have potentially threatened the country's religious tolerance, civil Islam, and civic pluralism. Moreover, it is suggested that the rise of Islamist groups could likely transform Indonesia into an intolerant Islamist country. However, this article asserts that the Islamist groups are unlikely to reform Indonesia into an Islamic State or Sharia-based government and society, and are unable to receive the support and approval of the Indonesian Muslim majority due to the following fundamental reasons: the groups' internal and inherent weaknesses, ruptured alliance among the groups, lack of Islamist political parties, limited intellectual grounds of the movement, the accommodation of some influential Muslim clerics and figures into the central government body, and public opposition toward the Islamist groups.
\end{abstract}

Keywords: Islamism, Islamist movement, civil Islam, Muslim society, Islamist radicalism, peaceful Islamist mobilization, religious pluralism.

\section{Introduction}

One of the consequences observed in Indonesia after the downfall of Suharto in May, 1998 was the surge in Islamism. Bassam Tibi (2012), a prominent scholar of Islamic politics, defined Islamism as a political ideology based on a reinvented version of Islamic laws or a political ideology that strives to derive legitimacy from Islam. Islamism differs substantially from the religious faith of Islam, albeit its concepts are derived and based on certain Islamic 
texts, doctrines, discourses, and Qur'anic injunctions. Unlike Islam, Islamism can be described as a political-based fundamentalist movement that seeks to influence Muslim societies by deriving its programs, activities, platforms, and ideologies from specific Islamic discourses and texts (Hwang, 2009; Hilmy 2010).

Islamism and religious radicalism in Indonesia has been underway for more than twenty years. The rise of Islamism in the country have led to an escalation of various negative consequences and measures undertaken, such as: collective riots, terrorist acts, and violent conflicts; the imposition of the implementation of Sharia-based regional law (Peraturan Daerah) in several provinces, regencies, and municipalities; religious inspired anti-pluralist movements and intolerant actions; threats to wipe out non-Muslims and minority groups (e.g. religious sects, ethnicities, or even Muslim groupings); violent rallies to thoroughfares and town squares to demand the reformation of Indonesian ideology (i.e. Pancasila) and Constitution (i.e. UUD 1945) with Sharia, Islamic state, or caliphate; public gatherings organized by Islamist organizations to mock and accuse the Indonesian President, Joko Widodo, for being less-Islamic and anti-Islam for establishing diplomatic alliances with 'infidel countries', among others.

During the Jakarta's gubernatorial election in 2017, Islamist groups had used various dirty propaganda and black campaigns that included manipulating Islamic texts, discourses, and symbols to win the heart and minds of everyday Muslims to gain support for their preferred candidate (Anies Baswedan) over their rival (Basuki Tjahaja Purnama) (Hatherell \&Welsh, 2017; Al Qurtuby, 2019). Furthermore, the groups used strategies and tactics such as terrorizing, intimidations, threats, riots, and hate speeches (Bahasa Indonesia: ujaran kebencian) to induce fear within the public. Ishita Sharma (2019) defined hate speech as a verbal expression that is designed to promote hatred based on race, religion, ethnicity and violence between different communities. There are individuals and groups that have continued to use hate speeches to provoke violence between the masses and to further enhance their vested interest. The militant Islamist groups continued to employ their dirty campaign and strategies across Jakarta and other regions in the country during the municipal, district or gubernatorial elections (in 2017 and 2018), and during the presidential election in 2019. Fortunately, their attempts to disrupt the political climate was futile.

The illustration above seems to suggest that Indonesia has transitioned from tyranny to anarchy-from state violence committed by the former New Order regime, to mass anarchism carried out by a small fringe of militant Islamists or practitioners (individual or group) of Islamism. However, such distinctions have helped redefine the perceptions of Indonesian Islam (Fealy, 2004). Van Bruinessen (2013) suggested that the post-Suharto's Indonesian Islam took a "conservative turn", marked by the rise of Islamic conservatism, radicalism, Islamism, religious militancy, and religiously inspired militant Muslim groups and social organizations.

These conservative and Islamist notion do not represent the true teachings of Islam and the Muslim society in the archipelago. However, the rise in Islamism have changed and challenged the image and perception of Indonesian Islam, which was previously seen as 
peaceful, tolerant, secular, moderate and democratic (see Hefner, 2000; Pringle, 2010), but it is now seen as intolerant, violent, religious, pious, extreme and less-democratic (Sidel, 2006; Ramakrishna, 2014; Harsono, 2019).

While some scholars have addressed the emergence of Islamism in contemporary Indonesia, literature on the effects of Islamist movements and mobilizations towards the future of 'civil Islam' is relatively rare, if not entirely absent. Moreover, the past and recent studies, with a few notable exception, tend to neglect the variety and implementation of Islamism in contemporary Indonesia.

This article aims to understand the plurality and complexity of Indonesian Islamism, investigate the factors that contributed to the reemergence of Islamist groups and 'uncivil Islam, examine Indonesian responses towards the Islamist movement, and identify the challenges and prospects for civic pluralism and development of civil Islam in Indonesia. The main question that needs to be answered in this article is: Do the teachings and characteristics of Indonesian Islam have shifted from civil Islam to 'uncivil Islam', from civic pluralism to anti-pluralism, and from democratic to anti-democratic Islam?

This article suggests that various forms of Islamist groups and organizations-both militant and anti-militant-do exist in the post-New Order Indonesia, and therefore, have continued to challenge the country's ethno-religious plurality, cultural heterogeneity, and its philosophical and ideological foundations. To even consider Indonesian Islam as an 'uncivil Indonesian Islam' today is a misleading exaggeration. Such perceptions tend to ignore facts and the actions of democratic, tolerant and pluralist Muslims who have lived peacefully with other non-Muslims that have worked across ethno-religious boundaries to preserve their territories and societies from the influences of uncivil groups to ensure civic pluralism and civil Islam across the archipelago.

This article employed a historical and textual analysis to examine the history, and current developments of Indonesia's Islamism and Muslim groups to gain a better understanding of the changes that might occur among Islamists and non-Islamists in the country. The data gathered for analysis in this article were obtained from media reports, research findings from notable research institutions, secondary writings, and primary documentations of various Islamic institutions in Indonesia. Once the data was collected, the etic approach based on Max Weber's verstehen (i.e. "emphatic understanding") was applied to interpret, analyze, and understand the data and social facts thoroughly. This article bridges the gap between previous and existing literature that lacks the analysis and investigation on the various forms of Islamism and Islamist groups, as well as the tolerant and peaceful dimensions of Indonesia's deep plural societies.

\section{Islamism in Indonesia and Beyond}

Since the collapse of the Ottoman Empire, the founding of the Muslim Brotherhood in the 1920s, and the triumph of the Khomeini-led 1979 Iranian Islamic Revolution, Islamism or Islamist movement has become a global, international, and transnational development 
around the world. It has spread from the Middle East and Africa to Europe, Central, South and Southeast Asia, including Indonesia (see e.g. Osman, 2017; Berridge, 2018; Freer, 2018; Hegghammer, 2010; Hwang, 2009; Platzdasch, 2009).

Although Islamism continues to be universal across the globe, its forms, institutions, platforms, implementations, strategies, tactics, objectives, and purpose are significantly different between areas, groups, and countries. In developing countries, particularly in the Middle East such as Afghanistan, Egypt, Algeria, Iraq, Syria, and Libya, Islamist movements have often taken a radical or militant form of struggle and jihadism. While in many developed and peaceful countries, the Islamists (i.e. practitioners of Islamism) tend to take on different forms, strategies and tactics.

For instance, Freer (2018) argued that the Islamist organization (i.e. Muslim Brotherhood) that operates in wealthy monarchical states of the Arabian Gulf, particularly Qatar, Kuwait, and United Arab Emirates, have managed to use less-violent or less-militant forms of struggle. They utilize the links between the social (e.g. informal personal networks) and political entities (e.g. government institutions) to gain influence in policymaking within these rentier states as the Islamist movements do not have the opportunity or capability to compete for power in the Gulf. In relation to Turkey and Malaysia, Hwang (2009) argued that the Islamist mobilization has also taken less-militant and radical forms.

Islamism is not static, but rather a fluid and changing ideology. Studies on post-Islamism supports this notion. In countries like Iran, Turkey, Egypt and many others, some Islamist factions have begun to accommodate certain forms of democracy, allow pragmatic choices to be made by individuals, changed their radical political platforms and approaches, and have transitioned their previous militancy approach to a more moderate approach in spreading their ideology (see e.g. Bayat, 2013; Shahibzadeh, 2016; Hwang, 2009; Shehata, 2009). The emergence of Muslim Democratic parties across the Middle East and Africa (e.g. the Wasat Party in Egypt) indicate the change and transformation of militant Islamism to moderate Islamism that adheres to a secular political regime, normative commitment to the rules of a democratic political system, and the democratic political representation of a religious identity (Yildirim, 2016). Indonesia have exhibited similar tendency and characteristics of moderate Islamism.

However, large number of studies have continued to assert the Islamist movement as a fixed, unchanging socio-religious groups that constantly commit violence and intolerance, and oppose democratic system and procedures. This in turn contradicts the fact that some Islamists (both ordinary people and elites) have begun to shift their approaches, practices, and actions within the society. Most of them are involved in promoting peaceful coexistence, civil tolerance, and anti-radicalism, thus, becoming agents of peace and nonviolence (see e.g. Hwang, 2018, Brauchler, 2019, 2015; Manuputty, 2017) while others have engaged in the process of democracy (e.g. participation in the formal democratic elections).

As elsewhere around the world, Islamism in Indonesia is a heterogeneous and complex phenomenon that needs to be broken down into smaller components. Indonesian Islamists 
do employ different methods and practices in the implementation of their agenda. Some groups pursue the establishment of an Islamic state or an Islamic government based on their notions, interpretations, understandings, or 'imaginations' of sharia from specific Islamic texts, teachings, and discourses. While some Islamists may simply want Islam to have a deeper role within in the society, others may want to enforce sharia and fiqh (Islamic jurisprudence) in the everyday life of Muslim communities or to establish the country's laws and regulations that are based entirely on the Islamic laws (at both national and regional levels). Additionally, some Islamists have further advocated the restoration of a supranational Islamic Caliphate as the ultimate goal (Platzdasch, 2009; Hwang, 2009).

Therefore, the Indonesian Islamists are far from being a monolithic ideological group as these groups have actively implemented multiple ritual practices and social-religious organizations, understood the Islamic teachings, interpreted religious texts and discourses, and devised various strategies to achieve their agenda. However, there are several distinctive Islamist movements in Indonesia, such as apolitical quietism (e.g. Tablighi Jamaat), political quietism (e.g. Hizbut Tahrir Indonesia), political pragmatism (e.g. Justice and Welfare Party), religious and moral reformism (e.g. Islamic Defenders Front), jihadist activism (e.g. Laskar Jihad), and Pan-Islamic terrorism (e.g. Jamaah Islamiyah). These distinctions must be examined carefully to avoid oversimplification in the study of the rise of Indonesia's Islamist groupings. Moreover, numerous literature on Indonesia's Islamist movements, with few notable exceptions, have emphasized the destructive roles of the violent, radical Islamist groups, while neglecting the cause and effects of less-violent Islamist movements.

It is imperative to note that Islamism is not new in Indonesia's social history. Although post-Suharto Indonesia has been marked by a surge of transnational Islamists and local conservative Muslim groupings, it is difficult to conclude that religious reformism, conservatism, radicalism and Islamism is a new phenomenon in the Indonesian history. Since the eighteenth century, the archipelago has been an arena of severe political struggle, Islamic contest, and harsh religious rivalry among various Muslim groupings: Islamists, reformists, traditionalists, modernists, nominal Muslims, Sufis, and sharia-oriented Muslims, among others (Ricklefs, 2012). Islamists and non-Islamist movements have been involved in religious contest to win the hearts and minds of Indonesian societies (Laffan, 2003).

The rise of Islamism in Indonesia, particularly its reemergence in the post-New Order era, was the product of multiple factors that included the changing international political dynamics and postcolonial conditions such as the Cold War (between Communist and Capitalist blocs), political opportunity in the post-independent period (e.g. the rise of Masyumi Islamist political party), the Iranian Islamic Revolution of 1979, and Suharto's pro-Western policies. These factors are attributed to the rise of ultraconservative extremist Islamism that have rhetorically denounced anti-Western (cultural) ideologies such as democracy, capitalism, liberalism, and secularism. The United States-led 'global war on terror' following the tragic terrorist incident of 9/11 that targets potential terrorists and extremists across the globe, may have also contributed to the rise and deepening of the militant Islamism in many parts of the world, including Indonesia. 
During the reigns of Presidents Sukarno (1945-67) and Suharto (1967-1998), militant Islamists had been severely treated, curbed and suppressed. However, despite these political repressions against the militant Islamists committed by Presidents Suharto and Sukarno, the groups never disbanded, and eventually, resurfaced and was heavily involved within the Indonesian political environment following the collapse of Suharto. In the aftermath of Suharto's fall in 1998, following financial and economic crises that hit the country since the mid-1990s, Islamists mobilization became more noticeable in the country's political stage. The increase of the contemporary Islamists and radical Muslim groups, directly or indirectly, was the product of political reformation, liberalism and democracy that ensued after the fall of Suharto.

Hence, it is proposed that the collapse of Suharto's government is one of the primary factors that contributed to the rise of the Islamist movements in the post-New Order Indonesia. During the early period of the New Order, Suharto severely controlled and ruthlessly treated Muslim reformist, militant groups and supporters of Islamism (van Bruinessen, 2002). Thus, following Suharto's collapse, these groups reemerged committed and determined to express their religious, cultural, ideological, political and economic interests. In the name of democracy and civil liberty, the conservative Muslim groups established Islamic centers, organizations, and schools as a means to disseminate anti-democratic ideas and thoughts of religious hatred and intolerance. This in turn allowed them to oppose democracy, which is viewed as a Western secular product.

Suharto's fall had led to many implications towards the Indonesian society. On one hand, it opened up opportunities for civil liberty, democracy and civic pluralism. However, it also provoked intolerance, radicalism and Islamic militancy. Despite some notable social, political, and economic developments, post-Suharto Indonesia was marked by the influx of local and transnational Islamist groupings that in turn have greatly challenged Indonesia's nascent democracy and fragile pluralism, and have tarnished the image of Indonesian Muslims as being intolerant when compared to their co-religionists in central Asia, the Indian subcontinent, and the Middle East. As a result, the increase of Islamist groups had led to many modernist and liberal views of the moderate and progressive Muslims to be challenged, or even rejected completely.

Essentially, Post-Suharto's democracy provided the opportunity for Islamism to flourish. In the name of freedom and democracy, various Islamist groups established Islamic centers, organizations, schools, and even political parties across the archipelago. They freely produced Islamic books and other publications that are in line with their Islamic ideas, interpretations, and understandings, and distributed them to the society through their extensive networks along with their socio-political agenda. Although these groups wish to live in the freedom provided under a democratic system, paradoxically, they use these Islamic institutions to disseminate intolerance, ethnocentrism and anti-pluralism to oppose democracy, which they view as a Western secular ideology. 
Another main factor that have contributed to the emergence of Indonesian Islamism is the occurrence of international and local Islamist-oriented religious education, and the rise of transnational Islamist organizations and movements. Transnational Islamist education and organizations / movements are always interlinked since the main primary movers, thinkers, and activists of Indonesian Islamism were alumni of international or local Islamist-oriented religious educational centers, either university or institutions in Yemen, Egypt, Saudi Arabia, India, Pakistan, and Indonesia. Some of the Islamic institutions of learning, where historically Indonesian Islamists have learned Islam, are as follows: Al-Iman University, Dar al-Hadith (Yemen), International Islamic University, Abu Bakr Islamic University (Pakistan), Dar al-Ulum Deoband (India), Al-Azhar University (Egypt), Al-Imam Muhammad bin Saud Islamic University, Islamic University of Medina (Saudi Arabia), LIPIA (Institute of Islamic and Arabic Studies, Jakarta) (Bubalo and Fealy 2005; Bubalo, Phillips, and Yasmeen 2011). Moreover, some Indonesia's Islamist organizations are branches of international political and religious movements such as Hizb ut-Tahrir (Palestine), Tablighi Jamaat (India), Ikhwanul Muslimin (Egypt), Jamaat-e-Islami (Pakistan), and Al-Qaeda (Afghanistan).

From all the international Islamist groups that have advocated Islamism in Indonesia, the Arab Muslim Brotherhood and the Pakistani Jamaat-e-Islami are the earliest Islamist organizations that influenced the Indonesian Muslim society, long before Hizb ut-Tahrir, Tablighi Jamaat, or Al-Qaeda. Between the early 1950s and 1960s, the two organizations were successful in influencing certain Indonesian (or Southeast Asian) Muslim circles. During these period, the teachings of Hassan al-Banna (1906-09; and later Sayyid Qutb, 1906-66) of the Muslim Brotherhood and Abul A'la Maududi (1903-79) of the Jamaat-e-Islami became popular among Indonesian Muslim scholars and leaders, such as Muhammad Natsir (1908-93), who was the founding member of the Masjumi political party (Sevea 2009; Luth 1999).

Since the 1950s (or maybe earlier), some Indonesian Islamist leaders were familiar with the teachings of these notable scholars. However, it was not until the late 1970s and early 1980s that the ideas and organizational methods of the Muslim Brotherhood and Jemaat-e-Islami became popular, particularly among urban and university Muslim activists in the archipelago. One of the main groups that was heavily influenced by these ideas was known as the Jamaah Tarbiyah. Islamism-influenced Muslim students also established the Lembaga Dakwah Kampus (LDK, the Campus Proselytizing Institute) in the 1980s due to political pressure from Suharto's government.

After the fall of Suharto that had eventually opened doors for democracy and freedom, there were many other notable scholars other than Hassan al-Banna, Abu A'la Maududi, and Sayyid Qutb who have shaped and influenced Indonesian Islamists, such as Shaikh Mukbil bin Hadi al-Wad'i, Shaikh Yahya al-Hajuri, Shaikh Abdulrahman al-Adeni, Shaikh Rabi al-Madkhali, Shaikh Taqiyuddin al-Nabhani, Shaikh Muhammad Nasiruddin al-Albani, Shaikh Saleh al-Fauzan, and Muhammad bin Saleh al-Uthaymin. Their teachings and works have been translated into the Indonesian language, published and distributed by Islamist networks around the country. 


\section{Violent Islamist Groups and Anti-Pluralist Movement}

There are multiple types of Islamist groupings, ranging from less-violent to violent militant groups. It is further proposed that not all Islamist groups commit physical violence, albeit they may commit other forms of violence. Therefore, it is inaccurate to define the character of Islamist mobilization has always being violent, militant, or radical. Similar to certain sects of Judaism and Christianity that instills into their adherents on the improvement of personal piety, many Islamic revivalist movements also encourage Muslims to become more observant. Hence, Islamist mobilizations, including those in Indonesia, can be violent or extremist, but at the same time there are groups who are peaceful or less-violent depending on their platforms, objectives, and strategies of movement.

Peaceful or less-violent Islamist mobilization may comprise of the following actions: forming political parties, contesting in elections, establishing alliances with other parties, developing state-civil society partnerships, and creating civil society organizations. Additionally, these groups may work with government agencies to establish Sharia-based policies. Violent or radical Islamist mobilizations may include attacks on property, acts of intimidation, targeting individuals or groups such as minority religious sects, minority ethnic groups or certain segments of the population that oppose their Islamists' goals and strategic choices, rioting, causing civilian unrest, communal violence, and political rebellion (Hwang, 2009).

Examples of less-violent Islamist groups include Tablighi Jamaat, Hizbut Tahrir Indonesia, Salafi (or neo-Salafi) groups. Organizations and groups that are categorized as intolerant and violent militant Islamist groups are as follows; Front Pembela Islam (Islamic Defenders Front), Laskar Jihad (Jihad Forces), Majelis Mujahidin Indonesia (Indonesian Jihadist Council), Jamaah Islamiyah, Jamaah Ansharut Tauhid, Forum Umat Islam (Islamic Umma Forum), Jamaah Ikhwanul Muslimin Indonesia (Association of Indonesian Muslim Brotherhood), Front Jihad Islam (Islamic Jihad Front), and Koalisi Nasional Anti-Syiah (Anti-Shia National Alliance).

There has been numerous cases of violence, intolerance, and anti-pluralism committed by various Islamist groups such as church burnings, terrorist bombings, destructions of religious properties and historical artifacts that belonged to non-Muslim groups (especially Christians but also Jews such as a synagogue in Surabaya of East Java), persecutions of religious minorities, harassment, and oppression towards critics of Islamist clerics and leaders. Among religious minorities, including Muslim minorities and local religious sects and beliefs (aliran kepercayaaan) that have been the target of persecution, maltreatment, and oppressions by radical Islamist groups include the Shiites, Ahmadis, Salamullah, al-Qiyadah al-Islamiyah, and most recently Gafatar (Gerakan Fajar Nusantara).

Recently, there has been several cases of violence against Christian leaders (e.g. an attack against Romo Prier or Pastor Karl Edmund Prier, SJ of St. Lidwina Church, Yogyakarta), churches, and communities. Members of Islamist groups in Yogyakarta (e.g. Front Jihad 
Islam), West Java (e.g. Forum Umat Islam), and Jakarta (e.g. Front Pembela Islam) have routinely committed acts of violence (direct or direct violence) against the Christian communities within these areas, apart from banning church-affiliated religious services and social activities.

In the attempt to understand and justify the reasons behind the acts of Islamism extremist on the devastations of churches and attacks on the Christian communities in the regions, it is important to note that there is a complex socio-historical cause for the violence that needs to be taken into account, and to not simply conclude it as the Muslim's anti-Christian campaign and propaganda. One the vital root causes is the rivalry between Christian Evangelical Churches (most of these churches are supported by American-based Evangelist Churches) and Islamist groupings that have been competing over new followers of migrant urban workers. The International Crisis Group (2010) report indicates that such competition, added with the harsh proselytization, has provoked both religious groups to commit violent conflicts. Moreover, it is highlighted that Indonesia's anti-Christian actions only occur in areas where Islamist groups have gained a foothold and are supported by the local communities and government such as in some districts in Jakarta, West Java, Banten, Aceh, Padang, and Yogyakarta. The rest of the country remains tolerant and peaceful with no record of Christian-Muslim violence. As of 2016, Indonesia has a total of 11,250 Catholic churches and 43,904 Protestant churches, whereby only several churches have been damaged by certain Islamist culprits.

Nonetheless, in the aftermath of Suharto's fall, there has been numerous cases of intolerance, violence and anti-pluralist movements committed by militant Islamist groups that have targeted both Muslim and non-Muslim minorities. Jakarta-based Setara Institute for Democracy and Peace reported a total of 371 incidents of religious violence in 2012, the highest level since 2007. These violent acts and anti-pluralist actions continue till today, particularly in areas such as West Java, Banten, and Jakarta. Many of these cases remain unresolved. Furthermore, the Islamist groups do not only preach intolerance, hate, and anti-religious pluralism during religious sermons held in mosques, in television channels, radios, campuses, squares, and other public places, or spread intolerant and anti-pluralist messages in social media (WhatsApp, Twitter, or Facebook), but they have also resorted to multiple forms of physical / direct violence to individuals or groups that they consider as enemies of Islam and the Muslim community as a whole.

Such Islamist extremism have grown significantly due to the absence of law enforcement and the lack of willingness and efforts by the government to curb radical Islamists. For the most part, the government only takes serious measures on terrorism. There has been a lack of initiative to tackle other forms of Islamist violence and extremism. Due to the governments' inefficiency in dealing with this problem, the Islamist hardliners continue to operate in disrupting multiple religious minority groups which they consider to be deviant sect or unlawful community. Despite relative success on the part of the government in apprehending some terrorists, it continues to fail in overcoming the rampant outbreaks of 
violent actions committed by these vigilante groups. In many cases, there has been evidence that some government officials and security personnel were involved in the incidents. The police officials have repeatedly stated that there were no radical Muslim organizations that were behind the attacks and violence against the minority groups. These events coupled with the police statements had raised concerns and suspicion that the government institutions and state apparatus were sometimes behind the violence. Amidst the chorus of criticism by religious moderates, human rights activists, university academicians and the public against these groups, they continue to carry out their violent actions and immoral deeds. When the government was not acting firmly and carrying out justice, these groups became a convenient pressure group.

This was observed during the reigns of Megawati Sukarnoputri (r. 2001-04), and became more evident during the tenure of Susilo Bambang Yudhoyono (r. 2004-14). During this period, the Islamists movement began gaining momentum and was highly regarded within the public as the Islamist leaders were successful in building close relationships with high-rank bureaucrats, ministers, vice president, politicians, and even with military and police personnel. However, under the presidency of Joko Widodo (r. 2014-19) who was viewed as a firm political leader, Islamist leaders could no longer enjoy the fruits of partnerships and relationships with the elite members of the central government and state apparatus as they slowly lost their position within the political power. However, this did not end the Islamist violence. Although they lost support from the central government, they had already built relationships with non-governmental elites, frustrated politicians, greedy businessmen, and unhappy former military and police generals. The Islamists movement was indeed strongly backed by these people, and was evident during the Jakarta's 2017 Gubernatorial Election.

\section{Jakarta's Islamist Mobilizations during Gubernatorial Election}

One of the examples of Indonesia's radical Islamist movement and mass mobilization took place during Jakarta's controversial and most heated gubernatorial election of 2017. The Jakarta Islamist mobilization was seen as the peak of militant Islamist movement, and was a forewarning to 'Islamist occupation' of the Indonesian state and society.

Of all the gubernatorial and municipal elections in the post-Suharto Indonesia, Jakarta's 2017 gubernatorial election (known as Pemilihan Kepala Daerah or Pilkada, and is sometimes known as Pemilihan Gubernur or Pilgub) was the worst and most violent election to date. The election was preceded by a series of violence, tension, uproar, terror, hatred, prejudice, intimidation, racism, ethnocentrism, and vicious Islamist mobilizations that were committed by multiple Islamist groups.

In the first round of the election, the Islamists' support was divided between Anies Baswedan (Anies), an Arab Hadrami origin, and Agus Harimurti Yudhoyono, the son of former Indonesian president Soesilo Bambang Yudhoyono. Agus Harimurti lost in the first round. 
However, in the second round, they were all united against the incumbent candidate Basuki Tjahaja Purnawa (known by his nickname 'Ahok', a Christian-Chinese) and his running mate Djarot Saiful Hidayat (Djarot), a Muslim of traditionalist-nationalist background.

Although tensions between supporters of the candidates were already brewing before the first round of the election, fierce conflict and competition took place in the second round of the election between the two sides; Anies-Sandi and Ahok-Djarot. Due to fear of the Islamist candidates (Anies-Sandi) would potentially lose the election, the Islamists conducted terror attacks, threats, and intimidations towards Jakarta's residents through mass rallies, public gatherings, religious sermons, Friday sermons, billboards, posters, and social media. Islamist, business and political leaders who backed Anies-Sandi had mobilized the ordinary masses in Jakarta and its neighboring areas (i.e. Banten and West Java provinces) to champion Islamism during marches, Friday sermons in town squares, prayers in carriageways, and in various public meetings.

Furthermore, the Islamist scholars and clerics had abused the religious teachings and doctrines, and manipulated Qur'anic texts and Islamic discourses for their own purpose and agenda (i.e. to provide theological and religious basis for the support of Anies). Through varied religious and Friday sermons, they regularly preached to the people that, as a Muslim, it is compulsory (wajib) to elect a Muslim (i.e. Anies) as their political and governmental leader, and is unlawful (haram) to choose a Christian (i.e. Ahok).

Islamist leaders were also preaching their propaganda in mosques, Islamic centers, television channels, and in various other media to intimidate Muslims, and emphasized that one would go to Hell after their death for whosoever chooses Ahok as their leader. They also threatened Muslims by stating that they would not pray and bury the bodies of those who supported Ahok. Additionally, the Islamists had also announced that they would terrorize Jakarta's residents if Ahok won the election, and would transform Jakarta into Hell by killing the Chinese, Christians, and Ahok supporters. They routinely warned people of the 'May Tragedy' of 1998 that took place in Jakarta, where the Chinese population became the target of violence by angry mobs.

Among the Islamist leaders, figures, clerics and televised preachers of multiple organizations who have aggressively attacked and offended Ahok and warned Muslims to not elect him by abusing Islamic texts, religious narratives and Qur'anic injunctions included, but not limited to, the following people: Muhammad Rizieq Shihab, Amin Rais, Tengku Zulkarnain, Bachtiar Nasir, Abdullah Gymnastiar, M. Arifin Ilham, Muhammad Al Khaththath, Athian Ali, Alfian Tanjung, Habib Zein al-Kaff, and Felix Siauw, among many others. The National Movement of Fatwa Guards of the Indonesian Ulama Council (Gerakan Nasional Pengawal Fatwa [Islamic edict] Majelis Ulama Indonesia) had joined forces with other non-Islamist anti-Ahok groups (i.e. groups that are anti-Chinese, and whom they dub as 'communist-atheist') and anti-non-Muslims groups (groups that consider non-Muslims as 'infidels') to mobilize ordinary Muslims across the country to hold a series of marches against Ahok, whom they accuse of conducting sacrilege and had urged the authorities to 
stand him for trial and withdraw him from the gubernatorial candidacy.

During the gubernatorial elections, the Islamists implemented violent and radical mobilizations to commit physical and verbal acts of violence that are anti-Christian and anti-Chinese with the aim of defeating Ahok, and influencing the Muslim community to choose Anies. In this period, the various Islamist groups that previously had different, and opposing strategies, tactics, objectives and agenda were suddenly united to oppose Ahok-Djarot whom they saw as the 'common enemy of Islam', despite the fact that Ahok's running mate, Djarot, is a devout Muslim.

The violent and radical Islamist mobilizations were successful. After a heated contest for Jakarta's governorship, the Indonesian General Elections Commission announced that Anies-Sandi won the election with 57.95 percent of the votes, while Ahok-Djarot received 42.05 percent Various reports from research institutes and media coverages indicated that a great number of Jakarta's residents, particularly Muslims, did not cast their votes for Ahok due to the following reasons; (1) they were afraid of the recurrence of anti-Chinese and anti-Christian riots, (2) they feared for breaking the rules of the Qur'an and would receive God's punishment, (3) they were worried that if they or their family members had died, no one would pray and bury their bodies, and (4) they wanted to obey the 'Qur'anic injunction' presented by the Islamist that instructs a Muslim to select another Muslim as their political leader. Hence, the election result clearly highlights the influence of religion and the Islamic identity during the Jakarta gubernatorial election.

Multiple factors had contributed to the Islamist mobilizations and rallies under the banner of 'Aksi Bela Islam' (Defending Islam Action) that was pitted against Ahok (Burhani 2017: 1-6). One of the factors was a video posted on YouTube and other social media that was being distributed and shared on the Internet. The video was posted by Buni Yani, an ardent Anies supporter, who was eventually arrested by the police and sentenced to several years in jail. The video contained an edited version of Ahok's speech in Seribu Island. In the original speech, Ahok warned Muslims to not be fooled by the Islamist teachers or 'ulama' (Islamic scholars and clerics) who have misinterpreted the Qur'anic verse (Al-Maida, 51) and have proclaimed that Muslims are banned from choosing a Christian to be a governor or any political leader in Muslim-majority areas.

His speech was then edited and manipulated by Buni Yani. In the edited version of the speech, Ahok's statements were manipulated to offend the Qur'an. This speech was uploaded on many social media sites that eventually sparked protests and angered the Muslim community, and called for Ahok to be arrested and sentenced for blasphemy. Due to increasing pressure from the Islamist groups, Ahok was eventually sentenced to two years in prison.

However, it is difficult to conclude that the manipulated speech was the main reason for the Islamist mobilization. Long before the speech was delivered, the Islamists were engaged in tensions and skirmish against Ahok, while some groups had even declared their own governor 
('gubernur tandingan'), named Fahrurrazi Ishak, to challenge the political authorities of Ahok, who was promoted in 2014 from deputy governor to governor of Jakarta when his running mate, Joko Widodo, left office to launch his successful presidential campaign.

Soon after Ahok assumed the gubernatorial post, his profile and popularity quickly skyrocketed and he became one of Indonesia's most prominent politicians. His popularity laid in his ability to reshape the political narrative by shifting the focus of 'Indonesia-ness' away from ethnic and religious identity to moral values that are based on transparency and integrity (Hatherell and Welsh 2017). Moreover, he was also famous for being committed and resolute in his fight for anti-corruption, clean governance, budget transparency, religious tolerance and civic pluralism; thereby becoming a threat to corrupt politicians, greedy businessmen, and radical Islamists who would eventually join forces to overthrow Ahok during the gubernatorial election.

Politicians, particularly in parliament (both central and Jakarta), viewed Ahok as the main threat to their immoral habits of committing corruption, whereas avaricious business people and conglomerates viewed Ahok as a committed and honest person who could not be bribed for their business developments and economic projects. Furthermore, the Islamists viewed Ahok to be the main risk to their 'Islamization' or 'Shariatization' agenda. This is considered as one of the reasons that led to Jakarta's mass mobilizations against Ahok.

Ahok's leadership and commitment to transform Jakarta into a leading metropolitan city by creating an effective, clean and transparent government that is built through democracy, tolerance, pluralism, civility and liberty have indeed threatened political, economic, and religious/ideological interests of the immoral politicians, gluttonous businessmen and extremist Islamists. Hence, these groups forged an alliance to overthrow Ahok in a coup by; (1) mobilizing ordinary people, urban Muslims, and religious fanatics and zealots, (2) conducting mass rallies and marches, (3) spreading terrors and hate speeches, (4) abusing mosques for political purposes, (5) manipulating religious texts and discourses, and (6) bribing poor urban people to vote against him.

Jakarta's violent and radical Islamist mobilization was only a means to pursue their economic and political aims. The Islamic narratives and ethnic identity proclaimed by these Islamists during the campaign were intended to conceal their worldly secular interests. In other words, the main purpose for the anti-Ahok campaigns (anti-Christian and Chinese) propagated by radical Islamist elites were not motivated by ultra-conservative religious (Islamic) ideas or the desire to implement Islamic values, norms, and laws in the country, but rather were driven by economic and political competition for power. Although, the ordinary masses of Islamist groups joined the anti-Ahok campaign with the impression of spreading religious motives and ideology, the Islamist leaders were clearly with the aim of seizing economic and political power in the country. In fact, many of the followers of Islamism were merely 'puppets' and 'peonage' for greedy businessmen, corrupt political leaders, and frustrated elite members of society. 


\section{Indonesia is not only Jakarta: Prospects and Challenges for Civil Islam and Civic Pluralism}

Although the results of Jakarta's gubernatorial election presented a bleak outlook on the future of Indonesia's civic pluralism and civil Islam, it is misleading to conclude the country's stance on Islamism based solely on the events that happen in Jakarta. To judge Indonesian Islam by Jakartan Islam is erroneous and misleading. It is also ambiguous to purely accept the Jakarta case as an anti-Chinese/non-Muslim election as there were also groups of Chinese and non-Muslims (especially Christians) who were supporting Anies, while there were Muslim groups who supported Ahok. Though the anti-Chinese and antinon-Muslim narratives were dominant during the gubernatorial elections (and continues till today), it is imprudent to suggest that Jakarta societies in general are anti-Chinese and non-Muslim.

Indonesia comprises of more states and regions other than Jakarta. In fact, there were 101 regions (provinces, districts, or municipalities) across Indonesia that have conducted direct elections to select the governor, regent or mayor in 2017. However, it was only in Jakarta that there were uncivil groupings (religious, political, or business groups) of Islamists who utilized prejudice, racism, religious sentiment, ethnic identity, and anti-Chinese / non-Muslim narratives for their political campaigns and mass mobilizations. In 2018, there were 171 regions in the country that held direct elections to choose their governor, mayor or regent. Subsequently, it was only in North Sumatra that the Islamists succeeded in manipulating voters and mobilizing the masses with religious (Islamic) sentiment.

Moreover, during the elections of the 101 regions in 2017, it was only in Jakarta that the Islamist mobilizations took place to defeat a non-Muslim candidate. Other regions, where non-Muslims and Chinese candidates were standing for election such as in Singkawang, Ambon, Landak, Kupang, Bolaang Mongondow, Maluku Tenggara Barat, Seram Bagian Barat, Maluku, West Papua, and many others ${ }^{1}$, there were no Islamist mobilizations that employed anti-Christian or non-Muslim, and anti-Chinese sentiments during the campaigns. Residents of these regions selected their governors, regents and mayors were mostly based on the candidate's track record, quality, credibility, capacity and capability to run the governments, and not on religious or ethnic identity. Many non-Muslims in several regions (e.g. Solo, Ambon, Landak, West Kalimantan, and others) had succeeded in winning their local election. Particularly, in the district of Singkawang of West Kalimantan, a non-Muslim Chinese woman, Tjhai Chui Mie, had won the municipal election.

In Jakarta, there was a great number of Muslims, especially those linked to Nahdlatul Ulama, whereby the country's largest Muslim organization, nationalist political parties and

Indonesian General Elections Commission (Komisi Pemilihan Umum) listed at least 22 regions during the 2017 election where non-Muslim run for candidacy. http://kbr.id/berita/02-2017/ini_22_pasangan_calon_ kepala_daerah_nonmuslim_yang_diusung_partai_islam/88775.html. Retrieved October 10, 2017. 
organizations, and the moderate middle class citizen were strongly against radical Islamist mobilizations for gubernatorial elections. Moreover, there were many Muslim groups in Jakarta that had supported Ahok, and argued that he was a more experienced, qualified and honest candidate than Anies.

Though the Jakarta's gubernatorial elections may have been a disappointment to Indonesian sovereignty, there is still hope for civil Islam and civic pluralism in Indonesia to ensure diversity, tolerance, democracy, and tolerant-in-pluralism. This is backed by strong evidence of inter-/intra-religious tolerance and cooperation within the society across the Indonesian archipelago, from Mentawai, North Sumatra and North Sulawesi to Bali, Flores and Kupang in eastern Indonesia. In 2018, Indonesia held 171 regional elections across the country to select the governor, mayor or regent. Interestingly, there was no single region that had employed prejudices, racism, ethnocentrism, or anti-non-Muslim sentiments in their campaigns to win the support of Muslim voters. However, the election is Jakarta was an exception.

In 2017, the Setara Institute for Democracy and Peace (Setara Institute) released the 'Indeks Kota Toleran' (Tolerance City Index) that rates the tolerant behavior for the residents and religious pluralism. Among 94 cities surveyed, Jakarta received the lowest score (2.30), followed by Banda Aceh (2.90). The top ten cities with the lowest scores of tolerance are documented in Table 1. There were many reasons behind Jakarta's rating as the country's most intolerant city. Some of these causes were due to social, economic, political, and religious factors. As the country's main hub for economic development and politics, Jakarta had attracted migrants from across the country to pursue jobs and opportunities that blends together people from diverse ethnicities and culture. With the population of more than 15 million people in 2019 (around 30 million for Greater Jakarta or Jakarta metropolitan area in 2014), Jakarta has become one of the most populous urban city on earth. Jakarta's nominal GDP (Gross Domestic Product) contributes to $17.5 \%$ of Indonesia's rapid economic growth. One of the outcomes of Jakarta's ethnoreligious complexity and economic development is that the region has become an arena for bureaucrats, businesspeople, politicians, religious leaders, ethnic chiefs, security forces, activists, gangsters, Muslim groupings, Islamist factions, and many others to gain influence and power. Jakarta is home to multiple Islamist groups whose members and supporters are often recruited from the Greater Jakarta's lowerincome class family, ordinary masses, and unemployed youths. Hence, this may have attributed to Jakarta's low tolerance and religious pluralism amongst its residents.

Apart from that, the Indonesian city that obtained the highest score of ethnoreligious tolerance and peaceful civic coexistence is Manado of North Sulawesi with a rating of 5.90, as recorded in Table 2. The survey examined factors such as the municipality's regulations, city government developmental plan (Rencana Pembangunan Daerah), discriminative public policies, government's acts and statements towards issues related to ethnoreligious communities and minority groups, among others. ${ }^{2}$

\footnotetext{
See http://setara-institute.org/indeks-kota-toleran-tahun-2017/
} 
Table 1

Top Ten Cities with Low Score of Tolerance

\begin{tabular}{clcc}
\hline No. & & City & Score \\
\hline 1 & Jakarta & 2.30 \\
2 & Banda Aceh & 2.90 \\
3 & Bogor & 3.50 \\
4 & Cilegon & 3.20 \\
5 & Depok & 3.30 \\
6 & Yogyakarta & 3.40 \\
7 & Banjarmasin & 3.55 \\
8 & Makassar & 3.65 \\
9 & Padang & 3.75 \\
10 & Mataram & 3.78 \\
\hline
\end{tabular}

Table 2

Top Ten Cities with High Score of Tolerance

\begin{tabular}{clcc}
\hline No & & City & Score \\
\hline 1 & Manado & 5.90 \\
2 & Pematangsiantar & 5.90 \\
3 & Salatiga & 5.90 \\
4 & Singkawang & 5.90 \\
5 & Tual & 5.90 \\
6 & Binjai & 5.80 \\
7 & Kotamabagu & 5.80 \\
8 & Palu & 5.80 \\
9 & Tebing Tinggi & 5.80 \\
10 & Surakarta & 5.72 \\
\hline
\end{tabular}

When compared to the 2015 City Tolerance Index (also released by Setara Institute), the findings were relatively similar, except the ratings for Jakarta and Bekasi. Jakarta dropped from 65 (in 2015) to 94 (in 2017), the lowest reading in the index. Meanwhile, Bekasi jumped from the second lowest intolerant city to 55. One of the interesting findings is that Yogyakarta was included in the top ten intolerant cities, despite its popularity as a city of education, student, tourism, and culture. Yogyakarta's rating in the index may be due to the increasing growth of various Salafi and Islamist groups in last decade. Based on surveys of several research studies, development and advocacy institutes, it is suggested that the religious intolerance behavior takes place in cities where most Islamist groups predominate, 
such as in Jakarta, Aceh, and in some cities in Banten and West Java. Other cities, where the Islamist groups are either passive or absent completely, are mostly tolerant, harmonious and less-violent.

Interestingly, several regions which were previously engaged in bitter ethnoreligious violence began to show positive outcomes toward religious tolerance and civil coexistence (Duncan, 2013; Khalikin and Fathuri, 2016). This may have been due to interreligious dialogue and peacebuilding that took place throughout Indonesia at the time. Even in regions that were previously beleaguered by lethal turmoil such as Ambon, North Maluku, Poso of Sulawesi, Sambas and Sampit in Kalimantan, the necessary efforts of ethnoreligious peacebuilding have been carried out since the initial conflict erupted in the late 1990s (Al Qurtuby 2013). This challenges the common belief and conventional wisdom of Indonesia's brutality, religious intolerance, and Islamist radicalism that have been widely reported in the media, policy studies, and many scholarly publications. Grassroots interreligious groups such as Baku Bae Movement, Peace Provocateurs, Jaka Tarub (Jaringan Kerja Antarumat Beragama), Komunitas Greenpeace, and Young Ambassadors for Peace are just a few examples of peacebuilding groups that promotes civil coexistence and religious harmony that enables communities to understand, and manage their differences in a more systematic manner to avoid violent conflicts.

A 2017 survey report by the Indonesian Ministry for Religious Affairs' Center for Research and Development of Religious Life (Pusat Penelitian dan Pengembangan Kehidupan Keagamaan) had shown an increase of religious tolerance and pluralism. The ministry also released a survey-based Religious Harmony Index, in which the index increased by 0.11 percent (about $75.47 \%$ ) from the previous year. The survey was based on three criteria, namely (interreligious) tolerance, equality and cooperation. From all three criteria, it was concluded that interreligious cooperation received the lowest score $(41.85 \%)$, while tolerance $(78.41 \%)$ and equality $(78.24 \%)$ had higher scores. During the presentation of the survey, the Minister of Religious Affairs, Lukman Hakim Saifuddin, promised to enhance interreligious collaboration in the future. He also pointed out that interreligious cooperation when building places of worship and religious-cultural matters have been a common practice in several areas in Indonesia such as North Sulawesi, Maluku, and Nusa Tenggara Timur. Additionally, the minister further proposed six key points to improve religious harmony and tolerance in the country, namely; (1) socialization of interreligious harmony law (i.e. Undang-Undang Kerukunan Umat Beragama), (2) increase of the role of regional government (Pemda) in interreligious social activities, (3) empowerment of religious harmony aspects via regional laws, (4) improvement of interreligious views and social activities, (5) advancement of preachers' understandings and thoughts on other religions, and (6) expansion of the role of religious leaders as a 'social glue' of the society ('Kementerian Agama Republik Indonesia', 2016).

The report from the Ministry for Religious Affairs seemed accurate, and was in accordance with the general perception of the Indonesian society. In general, it was evident that many 
Muslims and non-Muslims in a variety of cities and towns outside of Jakarta that comprised of non-Muslim-majority or Muslim-majority areas have indeed lived alongside one another peacefully for generation. In Java's biggest cities such as Surabaya (the provincial capital of East Java) and Semarang (the provincial capital of Central Java), inter/intra-religious cooperation and tolerance were still very well-preserved, with only minor incidents of inter/ intra-religious clashes. Most of the residents in these deeply metropolitan cities, including the Muslim community, tended to be more pragmatic (economically / business oriented societies) and less interested in issues that relate to religious debates and conflict. Muslim and non-Muslim collaboration in economic, political, and cultural sectors were considered a norm in these cities, where interreligious intolerance and violence were a rare phenomenon around these regions. ${ }^{3}$

Furthermore, interreligious cooperation and tolerance have also been observed in Jakarta's neighboring regions, most notably Kampung Sawah. Located within the municipality of Bekasi, Kampung Sawah is only $2 \mathrm{~km}$ (1.2 mile) away from Jakarta. With a population of 52,512 (in a 2016 census by 'Badan Pusat Statistik'), Kampung Sawah has been nominated by the Indonesian government as a paragon for interreligious tolerance and is lauded for its deep plural society that has lived peacefully for many years. In Kampung Sawah, there are multiple religious groups that have built their places of worship and religious institutions close to one another. There are about 27 mosques and 15 churches in Kampung Sawah, including some of the oldest buildings such as the Masjid Agung Al-Jauhar, Gereja Katolik Santo Servatius and Gereja Kristen Pasundan. The majority of the residents are Muslims (about 87\%), followed by Christians (from various church congregations), Buddhists and Hindus.

Although the town is predominantly Muslim, all the religions coexist peacefully. Zainal Arifin, a Muslim from Kampung Sawah, had stated that one must respect other religious followers as the Al-Qur'an (QS Al-Baqara: 256) has declared that no one can force someone to be a Muslim (La ikraha fi al-din-'No compulsion in religion'), and religious matter is a personal matter as the Qur'an (QS Al-Kafiruun: 6) clearly proclaims the following verse; lakum dinukum waliya din (Widhana, 2017). There are various ways to preserve the interreligious harmony within the society such as holding regular interreligious meetings, establishing informal interfaith dialogue groups (e.g. Ngeriung Bareng), broadcasting an interreligious radio show (e.g. Suara Kampung Sawah) that advertises activities in the area, working together and helping each other when religious group performs religious festivals and ceremonies or building worship places, maintaining the shared local traditions (e.g. Babarit), and selecting moderate and tolerant preachers, priests, pastors, or imams to ensure peace is constantly maintained.

I had written a brief post on my personal Facebook page to examine areas in Indonesia that have maintained interreligious harmony and peace, and areas with records of religious tension

3 See the annual report of Semarang-based Lembaga Studi Sosial dan Agama (eLSA) on religious freedom at http://elsaonline.com. 
and violence. In the post, I mentioned a plan visit to conduct research and comparative study on Indonesia's peaceful plural societies. Astonishingly, I received more than 1,200 replies that have suggested hundreds of regions across the archipelago with heterogeneous societies that maintained peaceful coexistence between ethnoreligious communities for generations. Moreover, apart from suggesting peaceful or less-violent areas (cities and countryside), the Facebook users also described their rationales on the areas chosen or suggested, in relation to inter/intra-religious tolerance and cooperation. They presented convincing facts on local societies, for both Muslims and non-Muslims, on the harmony and tolerance preserved by the residents despite unpleasant issues of religious intolerance that arose in Jakarta and its surrounding regions.

Many Muslims in areas such as Manado, Semarang, Kupang, Denpasar, Pontianak, Wonosobo, Batang, Kediri, and many had refused the establishment of religious organizations and social groupings that are linked to militant Islamist groups, and have rejected Islamist leaders from delivering religious sermon in their regions. In a response to Jakarta's radical Islamist movements, civil-pluralist democratic movements, championed by moderate, nationalist, modernist, and traditionalist Muslim groups, have thrived throughout the country to raise public awareness (as well as to warn the government) on the hazards and consequences of radical Islamism for the Indonesian state ideology (Pancasila), constitution (UUD 1945), and its deep plural societies. They have also organized a series of public gatherings in several major cities and virtual campaigns through social media to counter the Islamist movement, religious radicalism and intolerance. This civil-pluralist movement had eventually succeeded in convincing the government to take firm actions against Islamist groups that could potentially endanger the future of Indonesian diversity. For instance, the Indonesian government had issued a regulation (e.g. Perppu No. 2/2017) that bans any organization or social group whose platform, objectives and agenda contradict with the Indonesian state ideology and Constitution. The government has also banned Hizbut Tahrir Indonesia.

Moreover, in the aftermath of the Jakarta gubernatorial election, Islamist groups began to lose support from public Muslims since several leading Islamist figures and anti-Ahok supporters had become suspects (some sentenced in prison for several years) in various crimes ranging from pornography, hate speech, corruption and terrorist financing. One of the infamous Islamist leader, Rizieq Shihab, had fled Indonesia and is currently in Saudi Arabia. Thereafter, many Muslims who had previously supported anti-Ahok campaigns began to be more pessimistic, and eventually realized that they had been manipulated by Islamist leaders and anti-Ahok politicians.

Despite the negative and pessimistic views on the current development of Indonesian Islam, it is further asserted that the post-New Order Islamism will not be an ideology that would change Indonesia into an Islamic and Sharia-based nation-state, or transform the Indonesian multi-religious society to be a Muslim society that is supported by the country's Muslim majority, due to several major reasons. 
One of the most important reason is that the Islamists does not have a strong political party that could safeguard their agenda and interest. The Justice and Welfare Party (PKS) is pragmatic and opportunistic political party that has always been unreliable in various situations when addressing important issues within the society; thereby, not being an effective channel for Islamist groups to spread their ideology. PKS has been inconsistent in its pursuit of the party's agenda and platform. In Solo and Surakarta of Central Java, PKS had even supported a popular candidate for mayor: FX Hadi Rudiyatmo, who is a Catholic. Moreover, the Crescent Star Party (Parti Bulan Bintang, founded by Yusril Ihza Mahendra in 1998), which was an ex-Masyumi Islamist party, did not pass the minimum electoral threshold. In the 2009 legislative election, the party won 1.8 percent of the votes, less than the 2.5 percent of the electoral threshold. The Crescent Star Party lost all its seats in the People's Representative Council. The majority of Indonesia's political parties are either secular, nationalist, or moderate Islam.

Furthermore, the Islamists movement and its supporters are hardly united as a group. They have always been involved in harsh tension, clashes and conflict with one another due to differing opinions, ideas, interests, objectives, agenda, strategies, tactics, priorities, and ideological choices. There are Islamist groups that were established with the aim to transform Indonesia into an Islamic state (e.g. Majelis Mujahidin Indonesia or Jamaah Islamiyah) or a caliphate (e.g. Hizbut Tahrir Indonesia), while other groups aimed at implementing Sharia laws and incorporating it within the frameworks of the Unitary State of Republic of Indonesia (Negara Kesatuan Republik Indonesia) (e.g. Islamic Defenders Front or Islamic Community Forum). Other Islamists (e.g. some Salafi groupings) are less involved in the political arena, and are mainly involved in spreading the moral dimensions and theological aspects of the Muslim community.

In addition, the Islamist movement did not have a prominent figure that could unite the various Islamist groupings and attract support from the Indonesian Muslims. This may have been the cause on why the Islamists have always supported other non-Islamist contestants (e.g. Prabowo Subianto) who they think would pursue their religious, ideological, or even economic-political interests and agenda. Some Islamist leaders (e.g. Muhammad A1 Khaththath) had tried to run for office, but had lost in all of those election. Moreover, Islamist leaders, such as Rizieq Shihab whom his followers had dubbed him as 'Imam Besar Umat Islam' (the Grand Imam of Muslim Umma), had been a suspect in a pornography case that had subsequently tarnished his reputation and popularity. Since last year, Rizieq has been living in Saudi Arabia and faces multiple charges in the country such as violation of immigration law and residential permit, concealment of Indonesian illegal migrants, and recently, the installation of a flag in his residents that is linked to an unlawful Islamist organization.

The key role played by President Joko Widodo should also be highlighted. President Widodo skillfully pacified the Islamists by electing prominent non-Islamist figures (clerics or scholars) that were respected by the Islamist leaders into the government administration 
such as KH Ma'rufAmin (Chairman of Indonesian Council of Ulama, who became President Joko Widodo's running mate for the 2019 Presidential Election; now Vice President of Indonesia) and Mahfud MD (a former minister and judge of the Mahkamah Konstitusi-the Constitutional Court; and is now the Coordinating Minister for Politics, Law, and Security). At the time, Ma'ruf Amin and Mahfud MD had been appointed as advisors (along with seven other respected figures) of the Presidential Working Unit for the Implementation of the State Ideology of Pancasila (UKP-PIP). Besides President Widodo, the contributions made by General Tito Karnavian (National Police Chief of Indonesia, now Minister of Internal Affairs) was vital as he successfully tracked and brought down various terrorist networks and Islamist groups, and was able to prosecute some of their leaders in court for numerous cases ranging from hate speech, racism, terrorism, spreading of anti-government propaganda and desecrating the country's state ideology.

Moreover, it is also important to highlight the key roles played by the country's primary Muslim organizations that continue to be the backbone for tolerance and pluralism, such as the Nahdlatul Ulama and Muhammadiyah. These organizations have embraced a moderate stance in the defense of the country's ethnoreligious diversity. Since the founding of the Republic of Indonesia, prominent religious leaders from Nahdlatul Ulama have worked hand-in-hand with secular nationalists and Muslim democrats to create a public culture of citizenship and establish a political basis for a deeply plural society. By embracing the inclusive state ideology of Pancasila, they have challenged Islamist aspirations of building an Islamic state or caliphate, and establishing Sharia-based laws in the country. The efforts by Nahdlatul Ulama continue till today and has been a legacy that defends civic pluralism, civil Islam, and the state philosophical ideology.

In hindsight, based on the history of Indonesian Islam, Islamist groups have always lost its support and failed to win the hearts of the Muslim majority. This was partly due to; (1) the political conflict of ideology between the Old Order and the New Order governments, and (2) the nature and characteristics of the Islamist movement that inherently contradicts with the history, characteristics, traditions and culture of majority of the Indonesian society that favors inclusivism, pluralism, religious peace and tolerance. In general, the characteristics of Muslim Indonesians are 'nominal' (less-devout or less-religious), nationalistic and pragmatic, with little emphasis on militant and fanatical approach towards religious beliefs and practices. Many Muslim Indonesians consider themselves as 'wong nasional' (nationalist people) that points to their religious moderation and preference of nationality, rather than religiosity. The country's religious communities would not deliberate intolerance and strife provoked by immoral and greedy individuals (local, regional, or national) that have political, economic, and ideological interests in the society.

\section{Conclusion}

It is difficult and impetuous to suggest that today's Indonesian Islam has been completely influenced by Islamism. The 'battle of ideology' between the conservatives and progressives 
(i.e. Islamists and non-Islamists) is still ongoing, and the notion of plurality continues to take place in Islamic institutions and Muslim groupings. There are also a substantial number of moderate progressive figures within the MUI (Indonesian Council of Ulama). Although the actions and views of radical Islamists have been dominant in the media and scholarship, the truth, however, is entirely different. It is true that the Islamist groups are influential in Jakarta, and has been widely reported in various international media to suggest radical Islamism across the country. Nonetheless, this does not represent the image of Indonesian Islam as a whole. There are many important and prominent moderate-progressive Muslims across the country, including Jakarta.

Moreover, secular-nationalist and moderate Islamic political parties have constantly won the national and regional elections, suggesting that the Islamists ideology is not deeply ingrained into the hearts of the Indonesian society. The complexities and diversities of Muslim groupings suggest that Indonesia, with its prolonged experience of intergroup engagement and profound vigor for pluralism, has never been "Islamicized" or "Arabicised" by conservative and Islamist blocs. Therefore, it is optimistic to conclude that 'civil Islam' is not dead, and continues to be an important feature in this deeply plural archipelagic country for many years to come.

\section{Acknowledgement}

This research received no specific grant from any funding agency in the public.

\section{References}

Al Qurtuby, S. (2013). Reconciliation from below: Indonesia's religious conflict and grassroots agency for peace. Peace Research, 41(1), 135-62.

(2019). The 2019 election in Indonesia: The battle between "Jokowi Lovers" and "Jokowi Haters". The Maydan, April 24. https://www.themaydan.com/2019/04/the2019-election-in-indonesia-the-battle-between-jokowi-lovers-and-jokowi-haters/

Bayat, A. (2013). Post-Islamism: The changing faces of political Islam. Oxford, UK: Oxford University Press.

Berridge, W. J. (2018). Islamism in the modern world: A historical approach. London: Bloomsbury.

Brauchler, B. (2009). Reconciling Indonesia: Grassroots agency for peace. London: Routledge.

(2015). The cultural dimension of peace: Decentralization and reconciliation in Indonesia. London: Palgrave Macmillan.

Bubalo, A., \& Fealy, G. (2005). Joining the caravan? The middle East, Islamism, and Indonesia. Australia: Lowry Institute for International Policy.

Bubalo, A., Phillips, A., \& Yasmeen, S. (2011). Talib or Taliban? Indonesian students in Pakistan and Yemen. Australia: The Lowy Institute for International Policy. 
Burhani, A. N. (2017). Ethnic minority politics in Jakarta's Gubernatorial Election. Perspective 39, 1-6.

Duncan, C. (2013). Violence and vengeance: Religious conflict and its aftermath in Eastern Indonesia. Ithaca: Cornell University Press.

Fealy, G. (2004). Islamic radicalism in Indonesia: The faltering revival? Southeast Asian Affairs, 104-21.

Freer, C. (2018). Rentier Islamism: The influence of the muslim brotherhood in Gulf monarchies. Oxford, UK: Oxford University Press.

Harsono, A. (2019). Race, Islam and power: Ethnic and religious violence in post-Suharto Indonesia. Australia: Monash University Press.

Hatherell, M., \& Welsh, A. (2017). Rebel with a Cause: Ahok and Charismatic Leadership in Indonesia. Asian Studies Review, 41(2), 174-90.

Hefner, R. W. (2000). Civil Islam: Muslims and Democratization in Indonesia. New Jersey: Princeton University Press.

Hegghammer, T. (2010). Jihad in Saudi Arabia: Violence and Pan-Islamism since 1979. Cambridge, UK: Cambridge University Press.

Hilmy, M. (2010). Islamism and democracy in Indonesia: Piety and pragmatism. Singapore: Institute of Southeast Asian Studies.

Hwang, J. C. (2009). Peaceful Islamist mobilization in the muslim world: What went right. London: Palgrave MacMillan.

(2018). Why terrorists quit: The disengagement of Indonesian Jihadists. Ithaca, NY: Cornell University Press.

International Crisis Group (2010). Christianization and intolerance. Policy Briefing No. 114, November 24, 1-18.

Kementerian Agama Republik Indonesia (2016). Ikhtisar Eksekutif Laporan Tahunan Badan Litbang dan Diklat Kementerian Agama. Jakarta: Kementerian Agama RI.

Khalikin, A., \& Fathuri (2016). Toleransi beragama di daerah Rawan konflik [Religious tolerance in conflict areas]. Jakarta: The Ministry of Religious Affairs.

Laffan, M. (2003). The tangled roots of Islamist activism in Southeast Asia. Cambridge Review of International Affairs, 16(3), 397-414.

Luth, T. (1999). M. Natsir: Dakwah dan pemikirannya [M. Natsir: Proselytizing and his thoughts]. Jakarta: Gema Insani.

Manuputty, J., Salampessy, Z., Ali-Fauzi, I., \& Rafsadi, I. (2017). Basudara stories of peace from Maluku: Working together for reconciliation. Australia: Monash University Publishing.

Osman, T. (2017). Islamism: A history of political Islam from the fall of the Ottoman Empire to the rise of ISIS. Ithaca, NY: Cornell University Press.

Platzdasch, B. (2009). Islamism in Indonesia: Politics in the emerging democracy. Singapore: Institute of Southeast Asian Studies.

Pringle, R. (2010). Understanding Islam in Indonesia: Politics and Diversity. Honolulu: Hawaii University Press.

Ramakrishna, K. (2014). Islamist terrorism and militancy in Indonesia: The power of the Manichean mindset. Berlin, Germany: Springer. 
Ricklefs, M. C. (2012). Islamization and its opponents in Java. Singapore: NUS Press.

Sevea, Terenjit. (2009). Making Medinas in the East: Islamist connections and progressive Islam. In Feener, R. M., \& T. Seeva (Eds.). Islamic Connections: Muslim Societies and South and Southeast Asia. (149-174). Singapore: ISEAS-Yusof Ishak Institute.

Shahibzadeh, Y. (2016). Islamism and Post-Islamism in Iran. London: Palgrave Macmillan.

Sharma, I. (2019). Contextualizing hate speech: A study of India and Malaysia. Journal of International Studies, 15, 133-144

Shehata, D. (2009). Islamists and Secularists in Egypt: Opposition, conflict and cooperation. London: Routledge.

Sidel, J. (2006). Riots, pogroms, jihad. Religious violence in Indonesia. Ithaca, NY: Cornell University Press.

Tibi, B. (2012). Islamism and Islam. New Haven, CT: Yale University Press.

Van Bruinessen, M. ed. (2013). Contemporary developments in Indonesian Islam: Explaining the conservative turn. Singapore: Institute of Southeast Asian Studies. (2002). Genealogies of Islamic radicalism in post-Suharto Indonesia. South East Asia Research, 10(20), 117-154.

Widhana, D. H. (2017). Teladan toleransi dari kampung Sawah. TIRTO, 17 September. Retrieved from https://tirto.id/teladan-toleransi-dari-kampung-sawah-cwKp.

Yildirim, A. K. (2016). Muslim democratic parties in the Middle East: Economy and Politics of Islamist Moderation. Bloomington, IN: Indiana University Press. 